\title{
Update on the pathophysiology of cluster headache: imaging and neuropeptide studies
}

This article was published in the following Dove Medical Press journal: Journal of Pain Research

\section{Alina Buture ${ }^{1,2}$ \\ Jason W Boland ${ }^{2}$ \\ Lisa Dikomitis ${ }^{3}$ \\ Fayyaz Ahmed ${ }^{1,2}$}

'Department of Neurology, Hull Royal Infirmary, Hull, UK; ${ }^{2}$ Hull York Medical School, University of Hull, Hull, UK; ${ }^{3}$ School of Medicine and Institute of Primary Care and Health Sciences, Keele University, Newcastle, UK
Correspondence: Alina Buture

Department of Neurology, Hull Royal Infirmary, Anlaby Road, Hull HU3 2JZ, UK

Tel +447459872950

Email alina.buture@hey.nhs.uk
Objective: Cluster headache $(\mathrm{CH})$ is the most severe primary headache condition. Its pathophysiology is multifaceted and incompletely understood. This review brings together the latest neuroimaging and neuropeptide evidence on the pathophysiology of $\mathrm{CH}$.

Methods: A review of the literature was conducted by searching PubMed and Web of Science. The search was conducted using the following keywords: imaging studies, voxel-based morphometry, diffusion-tensor imaging, diffusion magnetic resonance imaging, tractography, connectivity, cerebral networks, neuromodulation, central modulation, deep brain stimulation, orexin-A, orexin-B, tract-based spatial statistics, single-photon emission computer tomography studies, positron-emission tomography, functional magnetic resonance imaging, magnetic resonance spectroscopy, trigeminovascular system, neuropeptides, calcitonin gene-related peptide, neurokinin A, substance $\mathrm{P}$, nitric oxide synthase, pituitary adenylate cyclase-activating peptide, vasoactive intestinal peptide, neuropeptide $\mathrm{Y}$, acetylcholine, noradrenaline, and ATP. "Cluster headache" was combined with each keyword for more relevant results. All irrelevant and duplicated records were excluded. Search dates were from October 1976 to May 2018.

Results: Neuroimaging studies support the role of the hypothalamus in $\mathrm{CH}$, as well as other brain areas involved in the pain matrix. Activation of the trigeminovascular system and the release of neuropeptides play an important role in $\mathrm{CH}$ pathophysiology. Among neuropeptides, calcitonin gene-related peptide, vasoactive intestinal peptide, and pituitary adenylate cyclase-activating peptide have been reported to be reliable biomarkers for $\mathrm{CH}$ attacks, though not specific for $\mathrm{CH}$. Several other neuropeptides are involved in trigeminovascular activation, but the current evidence does not qualify them as reliable biomarkers in $\mathrm{CH}$.

Conclusion: $\mathrm{CH}$ has a complex pathophysiology and the pain mechanism is not completely understood. Recent neuroimaging studies have provided insight into the functional and structural network bases of $\mathrm{CH}$ pathophysiology. Although there has been important progress in neuropeptide studies, a specific biomarker for $\mathrm{CH}$ is yet to be found.

Keywords: voxel-based morphometry, single-photon emission computer tomography, positronemission tomography, functional magnetic resonance imaging, calcitonin gene-related peptide, pituitary adenylate cyclase-activating peptide

\section{Introduction}

Cluster headache $(\mathrm{CH})$ is the most severe primary headache disorder. ${ }^{1} \mathrm{CH}$ has been called "suicide headache", because some patients have taken their lives during an attack or in anticipation of an attack. ${ }^{2}$ According to the International Classification of Headache Disorders, $\mathrm{CH}$ is defined as a unilateral condition, ${ }^{1}$ but bilateral attacks ${ }^{3}$ or alternating attack 
sides can occur. ${ }^{4} \mathrm{CH}$ is associated with ipsilateral conjunctival injection, lacrimation, nasal congestion, rhinorrhea, forehead and facial sweating, miosis, ptosis and/or eyelid edema, and/or with restlessness or agitation. A CH attack can last 15 minutes to 3 hours, occurring from every other day to eight times a day. ${ }^{1}$ The ways brain function are explored have revolutionized the understanding of pain mechanisms in headache disorders. Neuroimaging techniques and neuropeptide studies in $\mathrm{CH}$ are included in this review.

\section{Methods}

A review of the literature was carried out by searching PubMed and Web of Science. The search was conducted using the following keywords: imaging studies, voxel-based morphometry, diffusion-tensor imaging, diffusion magnetic resonance imaging, tractography, connectivity, cerebral networks, neuromodulation, central modulation, deep-brain stimulation, orexin-A, orexin-B, tract-based spatial statistics, single-photon-emission computed tomography studies, positron-emission tomography, functional magnetic resonance imaging, magnetic resonance spectroscopy, trigeminovascular system, neuropeptides, calcitonin gene-related peptide, neurokinin A, substance $\mathrm{P}$, nitric oxide synthase, pituitary adenylate cyclase-activating peptide, vasoactive intestinal peptide, neuropeptide Y, acetylcholine, noradrenaline, and ATP. "Cluster headache" was combined with each keyword for more relevant results (eg, "cluster headache" + "imaging studies", "cluster headache" + "neuropeptides"). All irrelevant and duplicated records were excluded from consideration. Works published from October 1976 to September 2018 are presented in the current review.

\section{Results}

\section{Imaging studies in $\mathrm{CH}$}

The first functional imaging studies in $\mathrm{CH}$ used singlephoton-emission computed tomography (SPECT). ${ }^{5-7}$ They were followed by positron-emission tomography $(\mathrm{PET})^{8,9}$ and functional magnetic resonance imaging (fMRI) studies. ${ }^{10,11}$ Structural imaging studies used voxel-based morphometry (VBM), diffusion-tensor imaging (DTI), tract-based spatial statistics (TBSS), and diffusion tractography. The findings of imaging studies are summarized in Table 1.

\section{Structural studies VBM}

VBM is a structural imaging technique that allows investigation of focal differences in brain anatomy, and it is mainly used to identify gray-matter alterations. Used in a pioneering study by May et al, ${ }^{12}$ VBM inspired many researchers to use the technique in the study of pain. It showed the involvement of the posterior hypothalamus in the pathophysiology of $\mathrm{CH} .{ }^{12}$ The study, conducted on 25 patients, detected significant structural differences (increase in volume) in gray-matter density among patients with $\mathrm{CH}$ compared to controls. ${ }^{12} \mathrm{~A}$ PET study on the same patient cohort showed activation of the same brain area. ${ }^{12}$ These findings led to the conclusion that the changes might be permanent and not a reaction to pain, showing a clear correlation between the structural and functional changes in $\mathrm{CH} .{ }^{12}$ Matharu, who reproduced the study, found no alterations in gray or white matter, suggesting that the initial finding might have been due to methodological limitations. ${ }^{13}$

A more recent study, carried out by Absinta et al, showed alterations in brain structures involved in pain processing (reduced gray-matter volume in the right posterior cingulate cortex, the head of the right caudate nucleus, right thalamus, left inferior parietal lobe, right middle temporal gyrus, left insula, right precentral gyrus, right precentral gyrus, and bilateral frontal gyrus). ${ }^{14}$ Using the same imaging technique, reduction in gray matter in frontal areas was detected in 49 patients with $\mathrm{CH}$, findings interpreted as dysfunction of the descending pain-modulation systems in $\mathrm{CH} .{ }^{15}$ The same study detected gray-matter increase in the anterior cingulate gyrus, insula, and fusiform gyrus, changes that could represent compensation mechanisms or neuroplasticity. ${ }^{15}$ The largest VBM study showed that brain alterations (temporal lobe, hippocampus, insular cortex, and cerebellum) were related to disease burden and variable in relation to the pain state. ${ }^{16}$

Although multiple studies have explored the role of the posterior hypothalamus in $\mathrm{CH}$, a recent study showed enlargement of the anterior hypothalamus in patients with both episodic and chronic $\mathrm{CH}$ compared with patients with migraine. ${ }^{17}$ Located in the anterior hypothalamus, the supraoptic nucleus, which is the endogenous biological clock, might cause the circadian and circannual periodicity that characterizes $\mathrm{CH} .{ }^{17}$

\section{DTI/TBSS/tractography}

DTI is an MRI technique used to estimate the axonal white-matter organization of the brain. The data are collected by diffusion weighted imaging. The main parameters measured with DTI are fractional anisotropy and diffusivity. ${ }^{18,19}$ Anisotropy is the property of being directionally dependent, which implies different properties in different directions, as opposed to isotropy. ${ }^{18}$ 
Table I Neuroimaging and biochemical studies

\begin{tabular}{|c|c|c|c|}
\hline & $\begin{array}{l}\text { Modality/analysis } \\
\text { method }\end{array}$ & $\begin{array}{l}\text { Subjects and } \\
\text { diagnosis }\end{array}$ & Main findings \\
\hline \multicolumn{4}{|c|}{ Structural studies } \\
\hline May et $\mathrm{al}^{12}$ & sMRI-T,W/VBM & $25 \mathrm{ECH}$ & Increase in bilateral posterior hypothalamic GM \\
\hline Matharu ${ }^{13}$ & sMRI-T,W/VBM & $66 \mathrm{ECH}$ & No significant changes in GM and WM \\
\hline Owen et $\mathrm{a}^{28}$ & $\begin{array}{l}\text { DW-MRI/probabilistic } \\
\text { tractography }\end{array}$ & $\mathrm{ICCH}$ & $\begin{array}{l}\text { No } \mathrm{CH} \text { attacks at } 8 \text { months after the DBS electrode was placed } 6 \mathrm{~mm} \\
\text { posterior to the hypothalamus, } 2 \mathrm{~mm} \text { lateral, and } 8 \mathrm{~mm} \text { below the } \\
\text { midcommissural point }\end{array}$ \\
\hline Absinta et $\mathrm{al}^{14}$ & sMRI-T,W/VBM and TBSS & $15 \mathrm{ECH}$ & $\begin{array}{l}\text { I. GM decrease in the pain network } \\
\text { 2. GM increase in the right cuneus } \\
\text { 3. No changes seen within the hypothalamus }\end{array}$ \\
\hline Teepker et $\mathrm{al}^{22}$ & sMRI-DTI/TBSS & $7 \mathrm{ECH}$ & Widespread WM alterations involved in trigeminal/nociceptive processing \\
\hline Seifert et $\mathrm{al}^{30}$ & $\begin{array}{l}\text { sMRI-T, W/whole-brain } \\
\text { surface-based comparison } \\
\text { of cortical thickness }\end{array}$ & $\mathrm{I} 2 \mathrm{ECH}$ & Cortical thinning in the contralateral angular and precentral gyrus \\
\hline Yang et al ${ }^{15}$ & sMRI-T,W/VBM & $49 \mathrm{ECH}$ & $\begin{array}{l}\text { I. GM-volume reduction in frontal areas } \\
\text { 2. GM increase in the ACC, fusiform gyrus, and insula (longitudinal analysis) }\end{array}$ \\
\hline Szabo et $\mathrm{a}^{23}$ & sMRI-DTI/TBSS & $13 \mathrm{ECH}$ & $\begin{array}{l}\text { Widespread reduction in FA and increase in diffusivity (contralateral } \\
\text { dominance) }\end{array}$ \\
\hline Naegel et al ${ }^{1 / 8}$ & sMRI-T,W/VBM & $\begin{array}{l}68 \mathrm{ECH}, \\
23 \mathrm{CCH}\end{array}$ & $\begin{array}{l}\text { GM-volume alterations in the temporal lobe, hippocampus, insular cortex, } \\
\text { and cerebellum }\end{array}$ \\
\hline Chou et $\mathrm{a}^{20}$ & sMRI-DTI/TBSS & $17 \mathrm{ECH}$ & $\begin{array}{l}\text { High diffusivity in the left frontal gyrus and lower diffusivity in the right } \\
\text { parahippocampal gyrus }\end{array}$ \\
\hline Kiraly et $\mathrm{a}^{24}$ & sMRI-T,W and DTI/FSL & $22 \mathrm{ECH}$ & $\begin{array}{l}\text { I. Increased FA of the right amygdala } \\
\text { 2. Increased diffusivity in the right caudate } \\
\text { 3. High radial diffusivity and lower anisotropy in the right pallidus }\end{array}$ \\
\hline Arkink et al ${ }^{17}$ & sMRI-T,W/VBM & $\begin{array}{l}24 \mathrm{ECH} \\
23 \mathrm{CCH} \\
14 \text { Probable } \\
\mathrm{CH}\end{array}$ & $\begin{array}{l}\text { Increased volume of the anterior hypothalamus in patients with } \mathrm{ECH} \text { and } \\
\mathrm{CCH} \text {; similar trends, but not significant in patients with probable } \mathrm{CH}\end{array}$ \\
\hline Akram et al ${ }^{26}$ & $\begin{array}{l}\text { DW-MRI/VBM/ } \\
\text { probabilistic diffusion } \\
\text { tractography }\end{array}$ & $7 \mathrm{CCH}$ & $\begin{array}{l}\text { The DBS-activated area posterior to the hypothalamus in the ventral } \\
\text { tegmental area lies on the tract that connects the hypothalamus, } \\
\text { prefrontal, and temporal regions with brain-stem area }\end{array}$ \\
\hline $\begin{array}{l}\text { Seijo-Fernandez } \\
\text { et } \mathrm{al}^{27}\end{array}$ & $\begin{array}{l}\text { DW-MRI/probabilistic } \\
\text { diffusion tractography }\end{array}$ & $\mathrm{I} 5 \mathrm{CCH}$ & $\begin{array}{l}\text { Projections between the DBS target areas and ipsilateral cerebellum and } \\
\text { reticular nucleus }\end{array}$ \\
\hline \multicolumn{4}{|c|}{ Functional studies } \\
\hline Norris et al ${ }^{5}$ & SPECT/ROI & $\mathrm{I} \mathrm{ECH}$ & No changes in mean CBF \\
\hline Sakai and Meyer ${ }^{6}$ & SPECT/ROI & $8 \mathrm{ECH}$ & Increased CBF \\
\hline Henry et $\mathrm{al}^{7}$ & SPECT/ROI & $3 \mathrm{ECH}$ & No changes in mean CBF \\
\hline Nelson et $\mathrm{al}^{|3|}$ & SPECT/ROI & $26 \mathrm{ECH}$ & Variable changes in mean CBF (increase or decrease) \\
\hline Krabbe et $\left.^{3}\right|^{32}$ & SPECT/ROI & $9 \mathrm{ECH}, 9 \mathrm{CCH}$ & No changes in mean CBF \\
\hline Di Piero et $\mathrm{al}^{33}$ & SPECT/ROI & $7 \mathrm{ECH}$ & $\begin{array}{l}\text { Decreased CBF in the posterior parietal cortex and thalamus contralateral } \\
\text { to the pain side }\end{array}$ \\
\hline Hsieh et $\mathrm{al}^{8}$ & PET/VBA and ROI & $7 \mathrm{ECH}$ & $\begin{array}{l}\text { I. Decreased rCBF in the frontal cortex, posterior parietal cortex, and } \\
\text { occipitotemporal regions } \\
\text { 2. Increased rCBF in the ACC, frontal cortex, insula, putamen, and } \\
\text { temporopolar region with preference of the right hemisphere }\end{array}$ \\
\hline May et $\mathrm{al}^{9}$ & PET/VBA & $9 \mathrm{CCH}$ & $\begin{array}{l}\text { I. Exclusive activation during } \mathrm{CH} \text { attacks of the inferior hypothalamic gray } \\
\text { matter ipsilateral to the headache side } \\
\text { 2. Increased rCBF in the ventroposterior thalamus, ACC, and insula } \\
\text { bilaterally }\end{array}$ \\
\hline May et al ${ }^{12}$ & PET/VBM & $17 \mathrm{ECH}$ & $\begin{array}{l}\text { Activation of inferior posterior hypothalamus ipsilateral to the headache } \\
\text { side }\end{array}$ \\
\hline May et $\mathrm{al}^{35}$ & PET and MRA/VBA & $17 \mathrm{ECH}$ & $\begin{array}{l}\text { I. Activation of inferior posterior hypothalamus, frontal lobes, insula } \\
\text { bilaterally, ACC bilaterally, ipsilateral thalamus, ipsilateral basal ganglia, and } \\
\text { contralateral inferior frontal cortex } \\
\text { 2. Increased CBF in the ICA ipsilateral to the headache side }\end{array}$ \\
\hline
\end{tabular}


Table I (Continued)

\begin{tabular}{|c|c|c|c|}
\hline & $\begin{array}{l}\text { Modality/analysis } \\
\text { method }\end{array}$ & $\begin{array}{l}\text { Subjects and } \\
\text { diagnosis }\end{array}$ & Main findings \\
\hline Sprenger et $\mathrm{al}^{36}$ & PET/VBA and ROI & $\mathrm{I} \mathrm{CHH}$ & $\begin{array}{l}\text { I. Activation of inferior hypothalamic gray matter } \\
\text { 2. Increased } \mathrm{rCRB} \text { in medial thalamus and contralateral ACC }\end{array}$ \\
\hline Sprenger et $\mathrm{al}^{37}$ & PET/VBA and ROI & $\begin{array}{l}6 \mathrm{ECH} \\
\mathrm{I} \mathrm{CCH}\end{array}$ & Decreased tracer binding in the pineal gland \\
\hline Sprenger et $\mathrm{al}^{38}$ & PET/VBA & II ECH & $\begin{array}{l}\text { I. Increases in metabolism in the ACC, posterior cingulate cortex, } \\
\text { prefrontal cortex, insula, thalamus, and temporal cortex } \\
\text { 2. Decreases in metabolism in the cerebellopontine area, perigenual ACC, } \\
\text { and prefrontal and orbitofrontal cortices }\end{array}$ \\
\hline Morelli et al ${ }^{10}$ & fMRI/VBA & $4 \mathrm{ECH}$ & $\begin{array}{l}\text { Activation of hypothalamus ipsilaterally to the pain side, prefrontal cortex, } \\
\text { ACC, contralateral thalamus, ipsilateral basal ganglia, insula bilaterally, and } \\
\text { cerebellar hemispheres }\end{array}$ \\
\hline Rocca et al' & $\mathrm{fMRI} / \mathrm{ICA}$ and SB-FCA & $\mathrm{I} 3 \mathrm{ECH}$ & $\begin{array}{l}\text { I. Decreased fluctuations in primary visual and sensorimotor networks } \\
\text { 2. Increased FC in the hypothalamus and thalamus }\end{array}$ \\
\hline Magis et $\mathrm{al}^{45}$ & FDG-PET & $\mathrm{IOCCH}$ & $\begin{array}{l}\text { Metabolic normalization in pain-matrix areas and absent short-term } \\
\text { changes induced by ONS }\end{array}$ \\
\hline Qiu et $\mathrm{al}^{41}$ & fMRI/SB-FCA & $12 \mathrm{ECH}$ & $\begin{array}{l}\text { Abnormal FC of the hypothalamus located mainly in the pain system } \\
\text { during spontaneous } \mathrm{CH} \text { attacks; extends beyond the pain system during } \\
\mathrm{CH} \text {-attack intervals }\end{array}$ \\
\hline Qiu et $\mathrm{al}^{42}$ & fMRI/ICA & $21 \mathrm{ECH}$ & $\begin{array}{l}\text { I. Decreased functional coactivation between the hypothalamus, both } \\
\text { ipsilateral and contralateral to the headache side } \\
\text { 2. SN in patients with right-sided or left-sided } \mathrm{CH}\end{array}$ \\
\hline Yang et $\mathrm{al}^{43}$ & fMRI/SB-FCA & $18 \mathrm{ECH}$ & $\begin{array}{l}\text { I. Hypothalamic FC changes with the medial frontal gyrus and occipital } \\
\text { cuneus during and outside } \mathrm{CH} \text { attacks } \\
\text { 2. Annual bout frequency correlated with hypothalamic FC in cerebellar } \\
\text { areas }\end{array}$ \\
\hline Chou et $\mathrm{al}^{44}$ & fMRI/ICA & I7 ECH & $\begin{array}{l}\text { I. FC changes in the temporal, frontal, salience, default mode, } \\
\text { somatosensory, dorsal attention, and visual networks, independently of } \\
\text { bout period } \\
\text { 2. Altered FC in the frontal and dorsal attention networks during } \mathrm{CH} \\
\text { attacks }\end{array}$ \\
\hline Farago et al ${ }^{119}$ & $\mathrm{fMRI} / \mathrm{ICA}$ & $17 \mathrm{ECH}$ & $\begin{array}{l}\text { Increased connectivity in attention network ipsilateral to the headache } \\
\text { side and in the contralateral cerebellar network }\end{array}$ \\
\hline Ferraro et $\mathrm{al}^{120}$ & RS-fMRI & $17 \mathrm{CCH}$ & $\begin{array}{l}\text { I. Increased functional connectivity between the posterior hypothalamus } \\
\text { and ventral tegmental area, dorsal raphe nuclei, bilateral substantia nigra, } \\
\text { subthalamic nucleus, and red nucleus } \\
\text { 2. No difference between patients and controls found in the contralateral } \\
\text { hypothalamic regions }\end{array}$ \\
\hline \multicolumn{4}{|c|}{ Biochemical studies } \\
\hline Montagna et $\mathrm{al}^{47}$ & ${ }^{31} \mathrm{P}-\mathrm{MRS} / \mathrm{ROI}$ & $14 \mathrm{CH}$ & $\begin{array}{l}\text { Reduced phosphocreatine levels, increased ADP concentration, reduced } \\
\text { phosphorylation potential, and high relative rate of ATP biosynthesis }\end{array}$ \\
\hline Lodi et $\mathrm{al}^{48}$ & ${ }^{31} \mathrm{P}-\mathrm{MRS} / \mathrm{ROI}$ & $\mathrm{I} 3 \mathrm{CH}$ & $\begin{array}{l}\text { Reduced cytosolic free } \mathrm{Mg}^{2+} \text { and free energy released by the reaction of } \\
\text { ATP hydrolysis }\end{array}$ \\
\hline Lodi et $\mathrm{al}^{49}$ & 'H-MRS/ROI & $\begin{array}{l}\mathrm{I} 8 \mathrm{ECH}, 8 \\
\mathrm{CCH}\end{array}$ & Reduced hypothalamic $\mathrm{N}$-acetylaspartate/creatine \\
\hline Wang et $\mathrm{al}^{50}$ & 'H-MRS/ROI & $47 \mathrm{ECH}$ & Reduced hypothalamic $\mathrm{N}$-acetylaspartate/creatine and choline/creatine \\
\hline
\end{tabular}

Abbreviations: ${ }^{31}$ P-MRS, phosphorus magnetic resonance spectroscopy; ACC, anterior cingulate cortex; CCH, chronic cluster headache; DBS, deep-brain stimulation; DTI, diffusion-tensor imaging; DW-MRI, diffusion-weighted magnetic resonance imaging; ECH, episodic cluster headache; FA, fractional anisotropy; FC, functional connectivity; FDG-PET, fluorodeoxyglucose positron-emission tomography; GM, gray matter; ICA, independent component analysis; ICA, internal carotid artery; 'H-MRS, proton MRS; MRA, magnetic resonance angiography; ONS, occipital nerve stimulation; rCRB, regional cerebral blood flow; ROI, region of interest; RS-fMRI, resting-state functional MRI; SB-FCA, seed-based functional connectivity analysis; SN, salience network; SPECT, single-photon-emission computed tomography; $T_{1}$ W, $T_{1}$-weighted; TBSS, tract-based spatial statistics; VBA, voxel-based analysis; VBM, voxel-based morphometry; WM, white matter; rCBF, regional cerebral blood flow; sMRI, structural MRI.

Fractional anisotropy is a scalar value from zero to one and describes the anisotropy of a diffusion process. Fractional anisotropy with a value of zero means the diffusion is isotropic (unrestricted or equally restricted in all directions). A value of one means that the diffusion affects one axis and is restricted along the other axis. ${ }^{19,20}$ Statistical analysis is performed using TBSS. ${ }^{21}$ TBSS uses nonlinear image transformation that combines 
the strength of both voxelwise and tractography-based analyses. $^{21}$

The VBM study performed by Absinta et al used a DTI/ TBSS analysis on the same sample of patients, but no significant change in fractional anisotropy or diffusivity was found. ${ }^{14}$ Another three studies that used DTI to explore brain changes in $\mathrm{CH}$ found widespread alterations in the painprocessing system ("pain matrix"). ${ }^{20,22,23}$ Interictal alterations in subcortical structures are present in $\mathrm{CH}$ (right amygdala, right caudate, right pallidus). ${ }^{24}$ Some of the microstructural changes are related to lifetime disease burden, suggesting that recurring painful episodes might trigger maladaptive plasticity or degenerative processes. ${ }^{24}$

Diffusion tractography is used to identify brain connectivity along white-matter pathways. ${ }^{25}$ Tractography studies have shown that the deep brain stimulation (DBS)-activated area lies in the ventral tegmental area, posterior to the hypothalamus, ${ }^{26-28}$ and projects to the ipsilateral cerebellum and reticular nucleus. ${ }^{28,29}$

\section{Other structural imaging studies}

Seifert et al conducted a high-resolution $T_{1}$-weighted MRI study and performed whole-brain surface-based comparison of cortical thickness. ${ }^{30}$ The study showed cortical thickening in patients with $\mathrm{CH}$, implying involvement of the cortical structures in the pathogenesis of $\mathrm{CH}^{30}$

\section{Functional studies SPECT}

SPECT was used as an early neuroimaging technique to evaluate cerebral blood flow by ${ }^{133} \mathrm{Xe}$ inhalation. Studies have shown varied results: some reported increases, ${ }^{6,31}$ others decreases, ${ }^{31}$ and some no changes ${ }^{5,7,32}$ in cerebral blood flow. The last SPECT study showed reduced cerebral blood flow in the thalamus and posterior parietal areas contralateral to the pain side, hypothesizing early on the involvement of these brain areas in $\mathrm{CH}$ pathophysiology. ${ }^{33}$

\section{PET}

PET is a nuclear medicine magnetic imaging technique that detects $\gamma$-rays emitted by a positron-emitting radionuclide (tracer). The biological molecule chosen for PET is fludeoxyglucose, an analog of glucose. ${ }^{34}$ Hsieh et al conducted the first nitroglycerin-induced PET study on seven patients with episodic $\mathrm{CH}$ in 1996, and showed activation of brain areas involved in central nociception with preference for the right hemisphere. ${ }^{8}$ Although the initial PET study did not show activation of the hypothalamus, a study conducted by May et al 2 years later showed activation of the inferior hypothalamic gray matter ipsilateral to the headache side during nitroglycerine-induced attacks. ${ }^{9}$ A later PET/magnetic resonance angiography study by the same group on a larger population of 17 patients with episodic $\mathrm{CH}$ showed activation of the inferior posterior hypothalamus and brain areas involved in pain processing. ${ }^{35}$ Significant dynamic changes in brain metabolism during and outside $\mathrm{CH}$ attacks were detected by three PET studies carried out by Sprenger et al. ${ }^{36-38}$

\section{fMRI}

fMRI measures brain activity by detecting changes associated with blood flow, and relies on the fact that blood flow and cerebral activation are coupled. When a brain area is active, the blood flow to that area increases. ${ }^{39}$ The primary form of fMRI uses blood-oxygen-level-dependent contrast and measures changes in blood flow and tissue oxygenation. ${ }^{39}$ Resting-state $\mathrm{fMRI}$ is a technique that assesses baseline brain activity when subjects are not performing any task, in contrast to task-specific fMRI. ${ }^{40}$ In the first fMRI study, Morelli et al showed activation of the hypothalamus during $\mathrm{CH}$ attacks and activation of other brain areas involved in pain processing. ${ }^{10}$ The role of the hypothalamus in the pathophysiology of $\mathrm{CH}$ was strengthened by several studies that found abnormal functional connectivity of the hypothalamus. ${ }^{11,41-44}$ Involvement of the pain matrix and nontraditional pain-processing areas (eg, salience networks, occipital area, cerebellar network) were also found..$^{40,44}$ Metabolic normalization in the pain-matrix areas and absent short-term changes induced by occipital nerve stimulation (ONS) might support the hypothesis that ONS, a symptomatic treatment for $\mathrm{CH}$, works through slow neuromodulation. ${ }^{45}$

\section{Biochemical studies}

${ }^{31} \mathrm{P}$ magnetic resonance spectroscopy (MRS) can be used as a noninvasive tool for measuring relative intracellular concentrations of phosphorus containing metabolites in different organs. ${ }^{46}$ Montagna et al conducted the first ${ }^{31} \mathrm{P}$-MRS study on 14 patients with $\mathrm{CH}$ and showed abnormalities in brainenergy metabolism, with reduced phosphocreatine levels, increased ADP, reduced phosphorylation potential, and high relative rate of ATP biosynthesis. ${ }^{47} \mathrm{~A}$ few years later, Lodi et al showed reduced cytosolic free $\mathrm{Mg}^{2+}$ and free energy released by the reaction of ATP hydrolysis. ${ }^{48}$ The first in vivo proton MRS ( $\left.{ }^{1} \mathrm{H}-\mathrm{MRS}\right)$ studies to show the involvement of the hypothalamus in $\mathrm{CH}$ pathophysiology were performed in 2006. ${ }^{49,50}{ }^{1} \mathrm{H}-\mathrm{MRS}$ allows noninvasive measurement of signal 
intensities derived from $N$-acetylaspartate, creatine, and phosphocreatine and choline-containing compounds. ${ }^{51}$ The studies showed reduced hypothalamic $N$-acetylaspartate:creatine ${ }^{49,50}$ and choline:creatine ratios ${ }^{48}$ in patients with $\mathrm{CH}$.

\section{Trigeminovascular pain pathways and neuropeptides}

\section{Anatomy of the trigeminovascular pain pathways}

The trigeminovascular system includes the trigeminal ganglion, the meningeal vasculature, and distinct nuclei of the brain stem, thalamus, and the somatosensory cortex (Figure 1). ${ }^{52}$ Pseudounipolar primary afferent fibers from the trigeminal ganglion synapse on intra- and extracranial structures. ${ }^{52}$ Nociceptive fibers innervating the pial, arachnoid, and dural blood vessels, including large cerebral arteries, superior sagittal sinus, and middle meningeal artery, arise from the trigeminal nerve, mostly $\mathrm{V} 1 .{ }^{53}$ On the other hand, sensory fibers innervating the posterior fossa and basilar arteries are located in the $\mathrm{C} 1-\mathrm{C} 3$ dorsal root ganglia. ${ }^{54}$ Projections from the trigeminal ganglion and upper cervical nerve roots converge at the trigeminocervical complex. Second-order neurons from the trigeminocervical complex ascend in the trigeminothalamic tract and synapse with third-order neurons. ${ }^{53}$ The third-order thalamocortical neurons synapse with a complex cortical network including the primary and secondary motor, sensory, and visual areas. ${ }^{53}$ There are direct and indirect ascending projections to the hypothalamus, periaqueductal gray, and locus coeruleus. ${ }^{55}$ There is a reflex connection from the trigeminal nucleus to the superior salivatory nucleus, which projects via sphenopalatine ganglion. ${ }^{53}$ Additional ascending projections exist to the insula, retrosplenial cortex, ectorhinal areas, rostral ventromedial medulla, parietal associations, and auditory areas. ${ }^{53}$

The thalamus is the relay center involved in the modulation and processing of all incoming sensory information. ${ }^{56}$ The pain matrix, which includes the thalamus, primary and secondary somatosensory areas, anterior cingulate gyrus, and prefrontal cortex, is active during nociceptive processing. ${ }^{56}$ Furthermore, indirect projections from the trigeminal nucleus to the amygdala and hippocampus are likely to be involved in the processing of cognitive and affective responses to pain. ${ }^{57}$

\section{Activation of the trigeminovascular system}

In vivo human studies have shown activation of the trigeminovascular system during acute $\mathrm{CH}$ attacks ${ }^{58}$ with distribution of pain in the ophthalmic division of the trigeminal nerve. ${ }^{1}$ Parasympathetic activation as a component of $\mathrm{CH}$ attacks

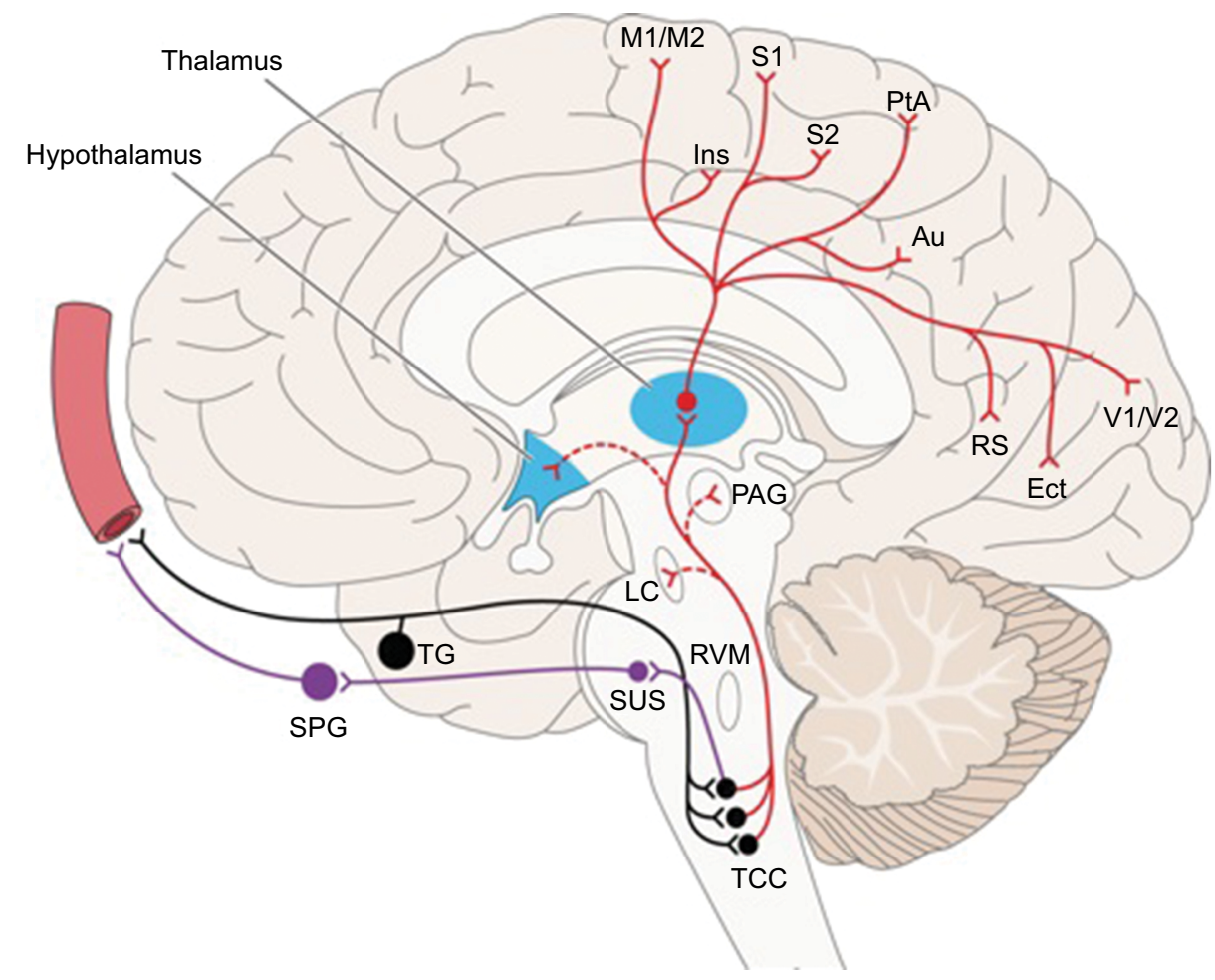

Figure I Ascending pathways of the trigeminovascular system.

Notes: Reproduced from Goadsby PJ, Holland PR, Martins-Oliveira M, Hoffmann J, Schankin C, Akerman S. Pathophysiology of migraine: a disorder of sensory processing. Physiol Rev. 2017;97(2):553-622.53

Abbreviations: TCC, trigeminocervical complex; SusS, superior salivatory nucleus; LC, locus coeruleus; Ins, insula; RS, retrosplenial; Ect, ectorhinal; RVM, rostral ventromedial medulla; PtA, parietal association area; Au, auditory association area; TG, trigeminal ganglion; SPG, sphenopalatine ganglion; PAG, periaqueductal grey; MI/M2, primary and secondary motor area, $\mathrm{SI} / \mathrm{S} 2$, primary and secondary sensory areas; $\mathrm{VI} / \mathrm{V} 2$, primary and secondary visual areas. 
involves the activation of the trigeminal-autonomic reflex, ${ }^{59}$ and manifests clinically as lacrimation, nasal congestion, and rhinorrhea. Activation of the parasympathetic fibers is mediated through the facial nerve. ${ }^{60}$ Sphenopalatine ganglion stimulation is known to relieve $\mathrm{CH}$ pain. ${ }^{61}$ The sympathetic overactivity could be explained by dilatation of the carotid artery secondary to parasympathetic activation and subsequent compression on the periarterial plexus of sympathetic fibers. ${ }^{62}$ However, parasympathetic overactivity alone could be responsible for the ocular sympathetic deficit. ${ }^{62}$

\section{Neuropeptides involved in trigeminovascular system activation}

Activation of the trigeminovascular system leads to neuropeptide release. Nerve fibers are classified based on their neuropeptide content. Trigeminal sensory fibers contain calcitonin gene-related peptide (CGRP), neurokinin A, substance P, nitric oxide synthase, and pituitary adenylate cyclase-activating peptide (PACAP), parasympathetic nerve fibers are rich in vasoactive intestinal peptide (VIP), neuropeptide $\mathrm{Y}$, acetylcholine, nitric oxide synthase, and PACAP, and sympathetic nerve fibers contain norepinephrine, ATP, and neuropeptideY (Table 2). ${ }^{52,53}$

\section{Trigeminal sensory nerve fibers CGRP}

CGRP is the most potent vasodilator and expressed mainly in the central nervous system. ${ }^{63}$ It contains 37 amino acids and has two isoforms: $\alpha$ CGRP (CGRP1), located in the central and peripheral nervous systems, and $\beta$ CGRP (CGRP2), distributed in the enteric nerve fibers. ${ }^{64}$ Although the role of CGRP has been studied extensively in migraine, several studies have shown the implication of CGRP in $\mathrm{CH}$ pathophysiology. ${ }^{58,65,66}$ Patients with spontaneous or nitroglycerine-induced $\mathrm{CH}$ attacks were found to have increased CGRP levels in the external jugular vein that was normalized after $\mathrm{O}_{2}$ inhalation or treatment with subcutaneous sumatriptan $6 \mathrm{mg} .{ }^{58,65,66}$ Phase III clinical trials with CGRP monoclonal antibodies are in progress for the preventive treatment of episodic and chronic CH (NCT03107052, NCT02797951).

\section{Substance $P$}

Substance $\mathrm{P}$ is the first responder to most noxious stimuli, and is an immediate defense, stress, repair, and survival system. ${ }^{67}$ Its receptor, neurokinin type 1 , is distributed in many tissue types and organs. ${ }^{67}$ Substance $\mathrm{P}$ is responsible for multiple functions. It is a potent vasodilator, ${ }^{68}$ has a role in inflammation initiating the expression of cytokines, ${ }^{69}$ and is involved in nociception and the regulation of mood disorders. ${ }^{70}$ Substance $\mathrm{P}$ activity can be measured indirectly by assessing opiate and somatostatin activity, both active in relieving $\mathrm{CH}$ attacks, which inhibit substance $\mathrm{P} .{ }^{71}$ Changes in substance $\mathrm{P}$ immunoreactivity have been shown during spontaneous and histamine-induced $\mathrm{CH}$ attacks, suggesting a possible involvement of substance $\mathrm{P}$ in $\mathrm{CH}$ pathophysiology. ${ }^{71}$ Trigeminovascular system activation in cats induces release of substance $\mathrm{P}$ in the extracerebral circulation. ${ }^{72}$ Decreased substance $\mathrm{P}$ after administration of hyperbaric $\mathrm{O}_{2}$ has been found in patients with $\mathrm{CH}$ compared to controls. ${ }^{73}$

Table 2 Craniovascular nerve fibers and their vasoactive neuropeptides

\begin{tabular}{|c|c|c|}
\hline & Neuropeptide/neurotransmitter & Role of neuropeptide/neurotransmitter \\
\hline \multirow{5}{*}{$\begin{array}{l}\text { Trigeminal sensory } \\
\text { nerve fibers }\end{array}$} & Calcitonin gene-related peptide & Vasodilatation and plasma extravasation ${ }^{63}$ \\
\hline & Neurokinin & Initiation of expression of cytokines ${ }^{74}$ \\
\hline & Substance $P$ & $\begin{array}{l}\text { Vasodilatation }{ }^{68} \text { and plasma extravasation }{ }^{69} \\
\text { Initiation of expression of cytokines }\end{array}$ \\
\hline & Nitric oxide synthase & $\begin{array}{l}\text { Regulates blood flow (vasodilatation) })^{86} \\
\text { Prevents platelet activation } \\
\text { Inhibits monocyte adhesion and leukocyte function } \\
\text { In }\end{array}$ \\
\hline & Pituitary adenylate cyclase-activating peptide (PACAP) & Vasodilatation $^{77}$ \\
\hline \multirow[t]{5}{*}{$\begin{array}{l}\text { Parasympathetic } \\
\text { nerve fibers }\end{array}$} & Vasoactive intestinal peptide & $\begin{array}{l}\text { Potent vasodilator }{ }^{89} \\
\text { Proinflammatory and anti-inflammatory effects }{ }^{89}\end{array}$ \\
\hline & Neuropeptide $Y$ & Vasodilatation $^{94}$ \\
\hline & Acetylcholine & $\begin{array}{l}\text { Vasodilatation }^{96} \\
\text { Mast-cell degranulation }\end{array}$ \\
\hline & Nitric oxide synthase & Vasodilatation $^{86}$ \\
\hline & PACAP & Vasodilatation $^{77}$ \\
\hline \multirow{3}{*}{$\begin{array}{l}\text { Sympathetic nerve } \\
\text { fibers }\end{array}$} & Norepinephrine & Potent vasoconstrictor ${ }^{101}$ \\
\hline & ATP & Vasoconstriction $^{100}$ \\
\hline & Neuropeptide $Y$ & Vasoconstriction $^{94}$ \\
\hline
\end{tabular}

Notes: Reproduced from Goadsby PJ, Holland PR, Martins-Oliveira M, Hoffmann J, Schankin C, Akerman S. Pathophysiology of migraine: a disorder of sensory processing. Physiol Rev. 2017;97(2):553-622.53 


\section{Neurokinin A}

Neurokinin A (formally known as substance K) has an important contribution to nociceptive processing and inflammatory response, initiating the release of cytokines. ${ }^{74}$ Neurokinin $\mathrm{A}$, together with CGRP and substance $\mathrm{P}$, is released from the caudal trigeminal nucleus of the rat during electrical stimulation of the trigeminal ganglion..$^{75}$ The main role of neurokinin A is vasodilatation. The order of potency is CGRP $>$ substance $\mathrm{P}>$ neurokinin $\mathrm{A} .{ }^{58}$

\section{PACAP}

PACAP is involved in the regulation of important biological functions and is located in the brain and peripheral organs, notably the endocrine pancreas, gonads, and respiratory and urogenital tracts. ${ }^{76}$ PACAP is found in both trigeminal sensory and parasympathetic fibers, and its main role is vasodilatation. ${ }^{77}$ Although the role of PACAP has been more extensively studied in migraine, ${ }^{78-80}$ it was shown that PACAP38 is released during $\mathrm{CH}$ attacks, with significantly low levels during the interbout period. ${ }^{81}$

\section{Nitric oxide synthase}

Nitric oxide synthases are a family of enzymes catalyzing the production of nitric oxide from L-arginin. ${ }^{82}$ Nitric oxide is a signaling molecule found in most tissue in the body. Among many other roles, nitric oxide controls neurotransmission and vascular tone ${ }^{82}$ Nitric oxide production is correlated with disease activity of inflammatory disorders, such as multiple sclerosis, ${ }^{83}$ systemic lupus erythematosus,${ }^{84}$ and bacterial meningitis. ${ }^{85}$ Nitric oxide synthase regulates blood flow (vasodilatation), prevents platelet activation, and inhibits monocyte adhesion and leukocyte function. ${ }^{86}$ Nitrates, which are reduced to nitric oxide in the body, are well-known headache triggers. ${ }^{82}$ Enhanced nitric levels have been found in the plasma ${ }^{87}$ and cerebrospinal fluid ${ }^{82}$ of patients with $\mathrm{CH}$ during active and remission periods. It has been shown that genetic variations within the nitric oxide synthase gene are less likely to contribute to $\mathrm{CH}$ susceptibility. ${ }^{88}$

\section{Parasympathetic nerve fibers VIP}

VIP is a peptide hormone of 28 amino-acid residues that belongs to a glucagon/secretin family. VIP is a potent vasodilator, and has proinflammatory and anti-inflammatory effects. ${ }^{89} \mathrm{VIP}$ is found in the parasympathetic nervous system and supraoptic nucleus, as well as the digestive and cardiovascular systems. ${ }^{90}$ Elevated VIP plasma levels have been found during $\mathrm{CH}$ attacks and migraine, suggestive of intense parasympathetic activation. ${ }^{72}$ Serum VIP, but not CGRP, levels seem to reflect the rate of activation of the parasympathetic arm of the trigeminovascular system in migraines, ${ }^{91}$ but there are no studies that have tested the same in patients with $\mathrm{CH}$.

\section{Neuropeptide $Y$}

Neuropeptide $Y$ is a 36 amino-acid neuropeptide and the most abundant peptide in the central and peripheral nervous systems. Neuropeptide $\mathrm{Y}$ is found in a high number of neurons of parasympathetic ganglia, but is produced mainly by the sympathetic nervous system. In the human brain, neuropeptide $\mathrm{Y}$ expression is highly concentrated in hypothalamic nuclei, basal ganglia, and the limbic system. ${ }^{92}$ Neuropeptide $\mathrm{Y}$ can modulate nociceptive trigeminovascular transmission in second-order neurons after peripheral systemic administration. ${ }^{93}$ Its main role is vasoconstriction, although it can also have a vasorelaxant effect. ${ }^{94}$ Early experiments did not find changes in neuropeptide $Y$ levels in the external jugular vein during $\mathrm{CH}$ attacks. ${ }^{72}$ This may suggest that a more localized locus of release, eg, the hypothalamic nuclei, would not detect neuropeptide $\mathrm{Y}$ in the extracranial vessels.

\section{Acetylcholine}

Acetylcholine is the neurotransmitter used at the neuromuscular junction, and is released by motor neurons to activate muscles. Acetylcholine is also used as a neurotransmitter in the autonomic nervous system, both as the final product released by the parasympathetic nervous system and as an internal transmitter for the sympathetic nervous system. ${ }^{95}$ Parasympathetic fibers originating from the sphenopalatine ganglion and trigeminal nerves release acetylcholine, VIP, and PACAP, provoking mast-cell degranulation and additional release of neurotransmitters, or they can directly affect trigeminal nerves inducing nociception. ${ }^{96} \mathrm{It}$ is well known that parasympathetic activation is present in $\mathrm{CH}$ and other primary headaches. Acute electrical stimulation of the sphenopalatine ganglion provides significant pain relief and significant and clinically meaningful reduction in $\mathrm{CH}$-attack frequency in some patients. ${ }^{61}$

\section{Sympathetic nerve fibers Norepinephrine}

Norepinephrine, also called noradrenaline, also produced by locus coeruleus in the pons, is used as a neurotransmitter by the sympathetic ganglia and released into the bloodstream by the adrenal glands. Norepinephrine is a potent vasoconstrictor. Tyrosine, ${ }^{97}$ tryptamine,${ }^{98}$ and tyramine ${ }^{98}$ metabolism, all involved in norepinephrine production, have been found to be abnormal in patients with chronic $\mathrm{CH}$. A primary autonomic 
dysfunction in $\mathrm{CH}$ is also suggested by increased $\beta$-receptor response to norepinephrine, as shown by Meyer et al. ${ }^{99}$

\section{ATP}

ATP is a complex chemical compound involved in intracellular energy transfer. ATP has several roles as an excitatory cotransmitter in the peripheral nerves. ${ }^{100}$ It is stored with noradrenaline in the synaptic vesicles in postganglionic sympathetic fibers and has vasoconstriction properties. ${ }^{100}$ Existing magnetic spectroscopy studies have shown abnormal energy metabolism in patients with $\mathrm{CH} \cdot{ }^{47,48}$

\section{Orexin $A$ and orexin $B$}

Hypocretin, also known as orexin, is produced in the lateral and posterior hypothalamus. The hypocretin neuropeptideprecursor gene encodes a neuropeptide-precursor protein that gives rise to orexin $\mathrm{A}$ and orexin $\mathrm{B}$, and is involved in a wide range of physiological processes, including pain transmission and neuroendocrine and autonomic function. ${ }^{102}$ HCRTR1 and HCRT2 are hypocretin receptors. A meta-analysis that included 593 patients with $\mathrm{CH}$ and 599 controls from three European studies showed that the 1,246G-A polymorphism (rs2653349) in the HCRTR2 gene may modulate the risk of $\mathrm{CH}{ }^{103-106}$ In contrast, the largest population-based study, conducted by Weller et al in 2015 on 575 patients with $\mathrm{CH}$ and 874 controls, found no evidence for association of rs2653349 and $\mathrm{CH}$, but a positive association was found in the meta-analysis conducted by the same authors on six previously published studies. ${ }^{107}$ The meta-analysis results should be interpreted with caution, as individual population studies have limited power and thus limited validity. ${ }^{107}$ A study on Chinese patients conducted by Fan et al (112 patients with $\mathrm{CH}$ and 192 controls) did not find a significant association between hypocretin-gene polymorphism and $\mathrm{CH} .{ }^{108}$ Given the inconsistency of the results from reported studies, the exact role of the HCRTR2 gene in $\mathrm{CH}$ is yet to be established.

\section{Discussion}

Structural and functional imaging studies have revolutionized our understanding of the pathophysiology of $\mathrm{CH}$. Several neuroimaging studies have identified differences between patients with $\mathrm{CH}$ and control subjects with respect to brain structure. Neuroimaging studies have shown a clear correlation between the structural and functional changes in $\mathrm{CH}$. The hypothalamus, an important component of the central nervous system that plays a role in homeostasis, autonomic, endocrine function, and nociception, ${ }^{109}$ has been hypothesized to play an essential role in initiating $\mathrm{CH}$ attacks. Neuroimaging findings have determined the use of stereotactic stimulation of the activated brain areas identified by structural and functional imaging. Although previous reports referred to the posterior hypothalamus as the optimal target, tractography studies have shown that the DBS-activated area is not located within the anatomically defined limits of the hypothalamus. ${ }^{26,110,111}$ The precise anatomical location for DBS refers to the midbrain tegmentum, rather than the posterior hypothalamus. ${ }^{29,111}$ The neurons in the ventral tegmental area project to multiple brain regions, and are involved in pain modulation, cognition, motivation, and behavioral disorders. ${ }^{112}$

Neuroimaging studies also implicate other brain areas generally associated with the pain matrix, such as various brain-stem areas, diencephalic structures, prefrontal cortex, basal ganglia, and parts of the limbic system. ${ }^{109}$ The pain matrix integrates all the sensory, affective, and cognitive responses to pain and becomes active during nociceptive processing. ${ }^{53}$ These areas are involved in a broad range of chronic painful diseases and are not specific for headache disorders. ${ }^{113}$ Abnormal metabolism in the perigenual anterior cingulate cortex suggests involvement in the descending antinociceptive processing in patients with episodic $\mathrm{CH}^{38}$ It is recognized that alterations in the central and descending opioid system contribute to the chronification of pain. ${ }^{114}$ The microstructural changes present in patients with $\mathrm{CH}$ are related to lifetime disease burden, suggesting that recurring painful episodes might trigger maladaptive responses. ${ }^{24}$

The release of neuropeptides as a consequence of trigeminovascular system activation has been proposed as a pain mechanism in $\mathrm{CH}$ and other primary headaches. ${ }^{115}$ The release of these peptides leads to a series of tissue responses, including arteriolar vasodilatation, plasma protein extravasation, and degranulation of mast cells in their peripheral target tissue. ${ }^{116}$ Among sensory neuropeptides, peripheral CGRP levels, ${ }^{58,65,66}$ VIP, ${ }^{91}$ and PACAP $38^{81}$ are reported to be good biomarkers of acute $\mathrm{CH}$ attacks. Serum VIP, but not CGRP, levels seem to reflect the rate of activation of the parasympathetic arm of the trigeminovascular system in migraine, ${ }^{91}$ but there are no studies that have tested the same in patients with $\mathrm{CH}$. Several other neuropeptides are involved in trigeminovascular system activation (substance $\mathrm{P}$, neurokinin $\mathrm{A}$, nitric oxide synthase, neuropeptide $Y$, acetylcholine, norepinephrine, ATP), but the existing evidence does not qualify them as reliable biomarkers in $\mathrm{CH}$. Although there is a real need for biomarkers in $\mathrm{CH}$, the current data must be interpreted with caution. The elevated levels of neuropeptides during $\mathrm{CH}$ attacks could only suggest activation of the trigeminovascular system, present in other primary headaches and not specific for $\mathrm{CH}$. 
Different sites, such as the ventral tegmental area, occipital nerve, sphenopalatine nerve, and vagus nerve have been recognized as relevant pain pathways in the pathophysiology of $\mathrm{CH}$. Neurostimulation of these pain pathways can influence central neurotransmitters. ${ }^{117}$ Invasive neurostimulation techniques are reserved for patients with refractory $\mathrm{CH}$.

\section{Conclusion}

Neuroimaging studies have reported three major findings: activation of the posterior hypothalamic area during $\mathrm{CH}$ attacks, involvement of the pain matrix, and involvement of the central opioid system. It is debatable whether the activation seen in these studies is of the midbrain tegmentum or the posterior hypothalamus. Among neuropeptides, CGRP, VIP, and PACAP38 are reported to be good markers of $\mathrm{CH}$ attacks, but they are not specific for $\mathrm{CH}$ and can only suggest activation of the trigeminovascular system. Neurostimulation therapies for refractory $\mathrm{CH}$, such as DBS, ONS, and sphenopalatine ganglion stimulation, are important tools in understanding $\mathrm{CH}$ pathophysiology.

\section{Author contributions}

All authors contributed to data analysis, drafting or revising the article, gave final approval of the version to be published, and agree to be accountable for all aspects of the work

\section{Disclosure}

The manuscript received no specific grant from any funding agency in the public, commercial, or not-for-profit sectors. The authors report no conflicts of interest in this work.

\section{References}

1. ICHD-3. Headache Classification Committee of the International Headache Society (IHS) The International Classification of Headache Disorders. 3rd ed. Vol. 38. Cephalalgia; 2018:1-211.

2. Robbins MS. The psychiatric comorbidities of cluster headache. Curr Pain Headache Rep. 2013;17(2):313.

3. Buture A, Hussain M, Ahmed F. A rare case of bilateral cluster headache - initially left sided cluster headache changing to a right sided cluster headache and subsequently to bilateral cluster headache. Eur J Neurol. 2016;23(S1):395. Available from: https://www.eaneurology. org/copenhagen2016/fileadmin/user_upload/EAN_Abstract_2016.pdf. Accessed December 21, 2018.

4. van Vliet JA, Eekers PJ, Haan J, Ferrari MD; Dutch RUSSH Study Group. Features involved in the diagnostic delay of cluster headache. J Neurol Neurosurg Psychiatry. 2003;74(8):1123-1125.

5. Norris JW, Hachinski VC, Cooper PW. Cerebral blood flow changes in cluster headache. Acta Neurol Scand. 1976;54(4):371-374.

6. Sakai F, Meyer JS. Regional cerebral hemodynamics during migraine and cluster headaches measured by the $133 \mathrm{Xe}$ inhalation method. Headache. 1978;18(3):122-132.
7. Henry PY, Vernhiet J, Orgogozo JM, Caille JM. Cerebral blood flow in migraine and cluster headache. Compartmental analysis and reactivity to anaesthetic depression. Res Clin Stud Headache. 1978;6:81-88.

8. Hsieh JC, Hannerz J, Ingvar M. Right-lateralised central processing for pain of nitroglycerin-induced cluster headache. Pain. 1996;67(1):59-68.

9. May A, Bahra A, Büchel C, Frackowiak RSJ, Goadsby PJ. Hypothalamic activation in cluster headache attacks. The Lancet. 1998;352(9124):275-278.

10. Morelli N, Pesaresi I, Cafforio G, et al. Functional magnetic resonance imaging in episodic cluster headache. J Headache Pain. 2009;10(1):11-14.

11. Rocca MA, Valsasina P, Absinta M, et al. Central nervous system dysregulation extends beyond the pain-matrix network in cluster headache. Cephalalgia. 2010;30(11):1383-1391.

12. May A, Ashburner J, Büchel C, et al. Correlation between structural and functional changes in brain in an idiopathic headache syndrome. Nat Med. 1999;5(7):836-838.

13. Matharu MS. Functional and structural neuroimaging in primary headache disorders. PhD Thesis. Institute of Neurology, University of London: London, UK; 2006.

14. Absinta M, Rocca MA, Colombo B, Falini A, Comi G, Filippi M. Selective decreased grey matter volume of the pain-matrix network in cluster headache. Cephalalgia. 2012;32(2):109-115.

15. Yang FC, Chou KH, Fuh JL, et al. Altered gray matter volume in the frontal pain modulation network in patients with cluster headache. Pain. 2013;154(6):801-807.

16. Naegel S, Holle D, Desmarattes N, et al. Cortical plasticity in episodic and chronic cluster headache. Neuroimage Clin. 2014;6: 415-423.

17. Arkink EB, Schmitz N, Schoonman GG, et al. The anterior hypothalamus in cluster headache. Cephalalgia. 2017;37(11):1039-1050.

18. Alba-Ferrara LM, de Erausquin GA. What does anisotropy measure? Insights from increased and decreased anisotropy in selective fiber tracts in schizophrenia. Front Integr Neurosci. 2013;7:9.

19. Basser PJ, Pierpaoli C. Microstructural and physiological features of tissues elucidated by quantitative-diffusion-tensor MRI. 1996. J Magn Reson. 2011;213(2):560-570.

20. Chou KH, Yang FC, Fuh JL, et al. Altered white matter microstructural connectivity in cluster headaches: a longitudinal diffusion tensor imaging study. Cephalalgia. 2014;34(13):1040-1052.

21. Smith SM, Jenkinson M, Johansen-Berg H, et al. Tract-based spatial statistics: voxelwise analysis of multi-subject diffusion data. Neuroimage. 2006;31(4):1487-1505.

22. Teepker M, Menzler K, Belke M, et al. Diffusion tensor imaging in episodic cluster headache. Headache 2012;52(2):274-282.

23. Szabó N, Kincses ZT, Párdutz Á, et al. White matter disintegration in cluster headache. J Headache Pain. 2013;14:64.

24. Király A, Szabó N, Párdutz Árpád, et al. Macro- and microstructural alterations of the subcortical structures in episodic cluster headache. Cephalalgia. 2018;38(4):662-673.

25. Descoteaux M, Deriche R, Knösche TR, Anwander A. Deterministic and probabilistic tractography based on complex fibre orientation distributions. IEEE Trans Med Imaging. 2009;28(2):269-286.

26. Akram H, Miller S, Lagrata S, et al. Optimal deep brain stimulation site and target connectivity for chronic cluster headache. Neurology. 2017;89(20):2083-2091.

27. Seijo-Fernandez F, Saiz A, Santamarta E, et al. Long-term results of deep brain stimulation of the mamillotegmental fasciculus in chronic cluster headache. Stereotact Funct Neurosurg. 2018;96(4): 215-222.

28. Owen SL, Green AL, Davies P, et al. Connectivity of an effective hypothalamic surgical target for cluster headache. J Clin Neurosci. 2007;14(10):955-960.

29. Clelland CD, Zheng Z, Kim W, Bari A, Pouratian N. Common cerebral networks associated with distinct deep brain stimulation targets for cluster headache. Cephalalgia. 2014;34(3):224-230. 
30. Seifert CL, Magon S, Staehle K, et al. A case-control study on cortical thickness in episodic cluster headache. Headache. 2012;52(9):1362-1368.

31. Nelson RF, du Boulay GH, Marshall J, Russell RWR, Symon L, Zilkha E. Cerebral blood flow studies in patients with cluster headache. Headache. 1980;20(4):184-189.

32. Krabbe AA, Henriksen L, Olesen J. Tomographic determination of cerebral blood flow during attacks of cluster headache. Cephalalgia. 1984;4(1):17-23

33. Di Piero V, Fiacco F, Tombari D, Pantano P. Tonic pain: a SPET study in normal subjects and cluster headache patients. Pain. 1997;70(2-3):185-191.

34. Sprinz C, Altmayer S, Zanon M, et al. Effects of blood glucose level on 18F-FDG uptake for PET/CT in normal organs: a systematic review PLoS One. 2018;13(2):e0193140.

35. May A, Bahra A, Büchel C, Frackowiak RS, Goadsby PJ. PET and MRA findings in cluster headache and MRA in experimental pain. Neurology. 2000;55(9):1328-1335.

36. Sprenger T, Boecker H, Tolle TR, Bussone G, May A, Leone M. Specific hypothalamic activation during a spontaneous cluster headache attack. Neurology. 2004;62(3):516-517.

37. Sprenger T, Willoch F, Miederer M, et al. Opioidergic changes in the pineal gland and hypothalamus in cluster headache: a ligand PET study. Neurology. 2006;66(7):1108-1110.

38. Sprenger T, Ruether KV, Boecker H, et al. Altered metabolism in frontal brain circuits in cluster headache. Cephalalgia. 2007;27(9):1033-1042.

39. Singleton MJ. Functional magnetic resonance imaging. Yale J Biol Med. 2009;82(4):233

40. Yang FC, Chou KH, Kuo CY, Lin YY, Lin CP, Wang SJ. The pathophysiology of episodic cluster headache: insights from recent neuroimaging research. Cephalalgia. 2018;38(5):970-983.

41. Qiu E, Wang Y, Ma L, et al. Abnormal brain functional connectivity of the hypothalamus in cluster headaches. PLoS One. 2013;8(2):e57896.

42. Qiu E, Tian L, Wang Y, Ma L, Yu S. Abnormal coactivation of the hypothalamus and salience network in patients with cluster headache. Neurology. 2015;84(14):1402-1408.

43. Yang FC, Chou KH, Fuh JL, et al. Altered hypothalamic functional connectivity in cluster headache: a longitudinal resting-state functional MRI study. J Neurol Neurosurg Psychiatry. 2015;86(4):437-445.

44. Chou KH, Yang FC, Fuh JL, et al. Bout-associated intrinsic functional network changes in cluster headache: a longitudinal resting-state functional MRI study. Cephalalgia. 2017;37(12):1152-1163.

45. Magis D, Bruno MA, Fumal A, et al. Central modulation in cluster headache patients treated with occipital nerve stimulation: an FDGPET study. BMC Neurol. 2011;11(1):25.

46. Klemm A, Rzanny R, Funfstuck R, et al. 31P-Magnetic resonance spectroscopy (31P-MRS) of human allografts after renal transplantation. Nephrol Dial Transplant. 1998;13(12):3147-3152.

47. Montagna $\mathrm{P}$, Lodi R, Cortelli $\mathrm{P}$, et al. Phosphorus magnetic resonance spectroscopy in cluster headache. Neurology. 1997;48(1):113-118.

48. Lodi R, Iotti S, Cortelli P, et al. Deficient energy metabolism is associated with low free magnesium in the brains of patients with migraine and cluster headache. Brain Res Bull. 2001;54(4):437-441.

49. Lodi R, Pierangeli G, Tonon C, et al. Study of hypothalamic metabolism in cluster headache by proton MR spectroscopy. Neurology. 2006;66(8):1264-1266.

50. Wang SJ, Lirng JF, Fuh JL, Chen JJ. Reduction in hypothalamic $1 \mathrm{H}-\mathrm{MRS}$ metabolite ratios in patients with cluster headache. J Neurol Neurosurg Psychiatry. 2006;77(5):622-625.

51. Terakawa $\mathrm{H}, \mathrm{Abe} \mathrm{K}$, Watanabe $\mathrm{Y}$, et al. Proton magnetic resonance spectroscopy (1H MRS) in patients with sporadic cerebellar degeneration. J Neuroimaging. 1999;9(2):72-77.

52. Tajti J, Szok D, Majláth Z, Tuka B, Csáti A, Vécsei L. Migraine and neuropeptides. Neuropeptides. 2015;52:19-30.

53. Goadsby PJ, Holland PR, Martins-Oliveira M, Hoffmann J, Schankin C, Akerman S. Pathophysiology of migraine: a disorder of sensory processing. Physiol Rev. 2017;97(2):553-622.
54. Keller JT, Saunders MC, Beduk A, Jollis JG. Innervation of the posterior fossa dura of the cat. Brain Res Bull. 1985;14(1):97-102.

55. Liu Y, Broman J, Zhang M, Edvinsson L. Brainstem and thalamic projections from a craniovascular sensory nervous centre in the rostral cervical spinal dorsal horn of rats. Cephalalgia. 2009;29(9):935-948.

56. Tracey I. Imaging pain. Br J Anaesth. 2008;101(1):32-39.

57. Jasmin L, Burkey AR, Card JP, Basbaum AI. Transneuronal labeling of a nociceptive pathway, the spino-(trigemino-)parabrachio-amygdaloid, in the rat. J Neurosci. 1997;17(10):3751-3765.

58. Goadsby PJ, Edvinsson L. Human in vivo evidence for trigeminovascular activation in cluster headache. Neuropeptide changes and effects of acute attacks therapies. Brain. 1994;117(Pt 3):427-434.

59. Benoliel R. Trigeminal autonomic cephalgias. Br J Pain. 2012;6(3): 106-123

60. Spencer SE, Sawyer WB, Wada H, Platt KB, Loewy AD. CNS projections to the pterygopalatine parasympathetic preganglionic neurons in the rat: a retrograde transneuronal viral cell body labeling study. Brain Res. 1990;534(1-2):149-169.

61. Schoenen J, Jensen RH, Lantéri-Minet M, et al. Stimulation of the sphenopalatine ganglion (SPG) for cluster headache treatment Pathway CH-1: a randomized, sham-controlled study. Cephalalgia. 2013;33(10):816-830.

62. Drummond PD. Autonomic disturbances in cluster headache. Brain. 1988;111(5):1199-1209.

63. Benarroch EE. CGRP: sensory neuropeptide with multiple neurologic implications. Neurology. 2011;77(3):281-287.

64. Tippins JR. CGRP: a novel neuropeptide from the calcitonin gene is the most potent vasodilator known. J Hypertens Suppl. 1986;4(5):S102-S105.

65. Fanciullacci M, Alessandri M, Figini M, Geppetti P, Michelacci S Increase in plasma calcitonin gene-related peptide from the extracerebral circulation during nitroglycerin-induced cluster headache attack. Pain. 1995;60(2):119-123.

66. Fanciullacci M, Alessandri M, Sicuteri R, Marabini S. Responsiveness of the trigeminovascular system to nitroglycerine in cluster headache patients. Brain. 1997;120(2):283-288.

67. Datar P, Srivastava S, Coutinho E, Govil G. Substance P: structure, function, and therapeutics. Curr Top Med Chem. 2004;4(1):75-103.

68. Bossaller C, Reither K, Hehlert-Friedrich C, et al. In vivo measurement of endothelium-dependent vasodilation with substance $\mathrm{P}$ in man. Herz. 1992;17(5):284-290.

69. Rameshwar P, Gascon P, Ganea D. Immunoregulatory effects of neuropeptides. Stimulation of interleukin-2 production by substance p. $J$ Neuroimmunol. 1992;37(1-2):65-74.

70. Ebner K, Singewald N. The role of substance P in stress and anxiety responses. Amino Acids. 2006;31(3):251-272.

71. Sicuteri F, Fanciullacci M, Geppetti P, Renzi D, Caleri D, Spillantini MG. Substance P mechanism in cluster headache: evaluation in plasma and cerebrospinal fluid. Cephalalgia. 1985;5(3):143-149.

72. Goadsby PJ, Edvinsson L, Ekman R. Release of vasoactive peptides in the extracerebral circulation of humans and the cat during activation of the trigeminovascular system. Ann Neurol. 1988;23(2):193-196.

73. Sabato FD, Giacovazzo M, Cristalli G, Rocco M, Fusco BM. Effect of Hyperbaric Oxygen on the Immunoreactivity to Substance P in the Nasal Mucosa of Cluster Headache Patients. Headache. 1996;36(4): 221-223.

74. Pantaleo N, Chadwick W, Park SS, et al. The mammalian tachykinin ligand-receptor system: an emerging target for central neurological disorders. CNS Neurol Disord Drug Targets. 2010;9(5):627-635.

75. Samsam M, Coveñas R, Ahangari R, Yajeya J, Narváez JA, Tramu G. Simultaneous depletion of neurokinin A, substance P and calcitonin gene-related peptide from the caudal trigeminal nucleus of the rat during electrical stimulation of the trigeminal ganglion. Pain. 2000;84(2-3):389-395.

76. Vaudry D, Falluel-Morel A, Bourgault S, et al. Pituitary adenylate cyclase-activating polypeptide and its receptors: 20 years after the discovery. Pharmacol Rev. 2009;61(3):283-357. 
77. Edvinsson L, Elsås T, Suzuki N, Shimizu T, Lee TJ. Origin and Co-localization of nitric oxide synthase, CGRP, PACAP, and VIP in the cerebral circulation of the rat. Microsc Res Tech. 2001;53(3): 221-228.

78. Tajti J, Tuka B, Botz B, Helyes Z, Vecsei L. Role of pituitary adenylate cyclase-activating polypeptide in nociception and migraine. CNS Neurol Disord Drug Targets. 2015;14(4):540-553.

79. Edvinsson L, Tajti J, Szalárdy L, Vécsei L. PACAP and its role in primary headaches. J Headache Pain. 2018;19(1):21.

80. Waschek JA, Baca SM, Akerman S. PACAP and migraine headache: immunomodulation of neural circuits in autonomic ganglia and brain parenchyma. J Headache Pain. 2018;19(1):23.

81. Tuka B, Szabó N, Tóth E, et al. Release of PACAP-38 in episodic cluster headache patients - an exploratory study. J Headache Pain. 2016;17(1):69.

82. O'Dell TJ, Hawkins RD, Kandel ER, Arancio O. Tests of the roles of two diffusible substances in long-term potentiation: evidence for nitric oxide as a possible early retrograde messenger. Proc Natl Acad Sci USA. 1991;88(24):11285-11289.

83. Johnson AW, Land JM, Thompson EJ, Bolanos JP, Clark JB, Heales SJ. Evidence for increased nitric oxide production in multiple sclerosis. $J$ Neurol Neurosurg Psychiatry. 1995;58(1):107.

84. Brundin L, Svenungsson E, Morcos E, et al. Central nervous system nitric oxide formation in cerebral systemic lupus erythematosus. Ann Neurol. 1998;44(4):704-706.

85. Kornelisse RF, Hoekman K, Visser JJ, et al. The role of nitric oxide in bacterial meningitis in children. J Infect Dis. 1996;174(1):120-126.

86. Förstermann U, Sessa WC. Nitric oxide synthases: regulation and function. Eur Heart J. 2012;33(7):829-837.

87. D'Amico D, Leone M, Ferraris A, et al. Role of nitric oxide in cluster headache. Ital J Neurol Sci. 1999;20(Suppl 1):S25-S27.

88. Sjöstrand C, Modin H, Masterman T, Ekbom K, Waldenlind E, Hillert J. Analysis of nitric oxide synthase genes in cluster headache. Cephalalgia. 2002;22(9):758-764.

89. Gonzalez-Rey E, Delgado M. Role of vasoactive intestinal peptide in inflammation and autoimmunity. Curr Opin Investig Drugs. 2005;6(11):1116-1123.

90. Achilly NP. Properties of VIP+ synapses in the suprachiasmatic nucleus highlight their role in circadian rhythm. $J$ Neurophysiol. 2016;115(6):2701-2704.

91. Riesco N, Cernuda-Morollón E, Martínez-Camblor P, et al. Relationship between serum levels of VIP, but not of CGRP, and cranial autonomic parasympathetic symptoms: a study in chronic migraine patients. Cephalalgia. 2017;37(9):823-827.

92. Adrian TE, Allen JM, Bloom SR, et al. Neuropeptide Y distribution in human brain. Nature. 1983;306(5943):584-586.

93. Martins-Oliveira M, Akerman S, Tavares I, Goadsby PJ. Neuropeptide Y inhibits the trigeminovascular pathway through NPY Y1 receptor: implications for migraine. Pain. 2016;157(8):1666-1673.

94. Tseng CJ, Robertson D, Light RT, Atkinson JR, Robertson RM. Neuropeptide $\mathrm{Y}$ is a vasoconstrictor of human coronary arteries. $\mathrm{Am}$ J Med Sci. 1988;296(1):11-16.

95. Tiwari P, Dwivedi S, Singh MP, Mishra R, Chandy A. Basic and modern concepts on cholinergic receptor: a review. Asian Pac J Trop Dis. 2013;3(5):413-420.

96. Mikhailov N, V Mamontov O, A Kamshilin A, Giniatullin R. Parasympathetic cholinergic and neuropeptide mechanisms of migraine. Anesth Pain Med. 2017;7(1):e42210.

97. D'Andrea G, Leone M, Bussone G, et al. Abnormal tyrosine metabolism in chronic cluster headache. Cephalalgia. 2017;37(2):148-153.

98. D'Andrea G, Bussone G, Di Fiore P, et al. Pathogenesis of chronic cluster headache and bouts: role of tryptamine, arginine metabolism and $\alpha_{1}$-agonists. Neurol Sci. 2017;38(Suppl 1):37-43.
99. Meyer EL, Waldenlind E, Marcus C. beta-Receptor response to noradrenaline in cluster headache. A study of adipose tissue lipolysis. Cephalalgia. 2006;26(7):831-836.

100. Kennedy C. ATP as a cotransmitter in the autonomic nervous system. Auton Neurosci. 2015;191:2-15.

101. Laverty R. Catecholamines: role in health and disease. Drugs. 1978;16(5):418-440.

102. Inutsuka A, Yamanaka A. The physiological role of orexin/hypocretin neurons in the regulation of sleep/wakefulness and neuroendocrine functions. Front Endocrinol (Lausanne). 2013;4:18.

103. Rainero I, Rubino E, Valfrè W, et al. Association between the G1246A polymorphism of the hypocretin receptor 2 gene and cluster headache: a meta-analysis. J Headache Pain. 2007;8(3):152-156.

104. Schürks M, Kurth T, Geissler I, Tessmann G, Diener HC, Rosskopf D. Cluster headache is associated with the G1246A polymorphism in the hypocretin receptor 2 gene. Neurology. 2006;66(12):1917-1919.

105. Rainero I, Gallone S, Valfrè W, et al. A polymorphism of the hypocretin receptor 2 gene is associated with cluster headache. Neurology. 2004;63(7):1286-1288.

106. Baumber L, Sjöstrand C, Leone M, et al. A genome-wide scan and HCRTR2 candidate gene analysis in a European cluster headache cohort. Neurology. 2006;66(12):1888-1893.

107. Weller CM, Wilbrink LA, Houwing-Duistermaat JJ, et al. Cluster headache and the hypocretin receptor 2 reconsidered: a genetic association study and meta-analysis. Cephalalgia. 2015;35(9):741-747.

108. Fan Z, Hou L, Wan D, Ao R, Zhao D, Yu S. Genetic association of HCRTR2, ADH4 and CLOCK genes with cluster headache: a Chinese population-based case-control study. J Headache Pain. 2018;19(1):1.

109. Neugebauer V. Subcortical processing of nociceptive information: basal ganglia and amygdala. Handbook of Clinical Neurology. 2006;81:141-158.

110. Akram H, Miller S, Lagrata S, et al. Ventral tegmental area deep brain stimulation for refractory chronic cluster headache. Neurology. 2016;86(18):1676-1682.

111. Matharu MS, Zrinzo L. Deep brain stimulation in cluster headache: hypothalamus or midbrain tegmentum? Curr Pain Headache Rep. 2010;14(2):151-159.

112. Moradi M, Yazdanian M, Haghparast A. Role of dopamine D2-like receptors within the ventral tegmental area and nucleus accumbens in antinociception induced by lateral hypothalamus stimulation. Behav Brain Res. 2015;292:508-514.

113. Sluka KA, Clauw DJ. Neurobiology of fibromyalgia and chronic widespread pain. Neuroscience. 2016;338:114-129.

114. Ossipov MH, Morimura K, Porreca F. Descending pain modulation and chronification of pain. Curr Opin Support Palliat Care. 2014;8(2):143-151.

115. Fusco M, D'Andrea G, Miccichè F, Stecca A, Bernardini D, Cananzi AL. Neurogenic inflammation in primary headaches. Neurol Sci. 2003;24(Suppl 2):S61-S64.

116. Malhotra R. Understanding migraine: potential role of neurogenic inflammation. Ann Indian Acad Neurol. 2016;19(2):175-182.

117. Oshinsky ML, Murphy AL, Hekierski H Jr, Cooper M, Simon BJ. Noninvasive vagus nerve stimulation as treatment for trigeminal allodynia. Pain. 2014;155(5):1037-1042.

118. Naegel S, Holle D, Obermann M. Structural imaging in cluster headache. Curr Pain Headache Rep. 2014;18(5):415.

119. Faragó P, Szabó N, Tóth E, et al. Ipsilateral alteration of resting state activity suggests that cortical dysfunction contributes to the pathogenesis of cluster headache. Brain Topogr. 2017;30(2):281-289.

120. Ferraro S, Nigri A, Bruzzone MG, et al. Defective functional connectivity between posterior hypothalamus and regions of the diencephalicmesencephalic junction in chronic cluster headache. Cephalalgia. 2018;38(13):1910-1918. 
The Journal of Pain Research is an international, peer reviewed, open access, online journal that welcomes laboratory and clinical findings in the fields of pain research and the prevention and management of pain. Original research, reviews, symposium reports, hypothesis formation and commentaries are all considered for publication
The manuscript management system is completely online and includes a very quick and fair peer-review system, which is all easy to use. Visit http://www.dovepress.com/testimonials.php to read real quotes from published authors.

Submit your manuscript here: https://www.dovepress.com/journal-of-pain-research-journal 